\title{
Government Financial Support and SME Development in Switzerland
}

\footnotetext{
Submitted 06/06/20, $1^{\text {st }}$ revision 11/07/20, $2^{\text {nd }}$ revision 25/08/20, accepted 15/09/20 Victoria V. Zabolotskaya ${ }^{1}$

Abstract:

Purpose: The goal of the study is to analyze model of government financing for small and medium-sized enterprises (SMEs) in Switzerland in order to apply its advanced experience to improve the system of federal financial support for SMEs in Russia.

Design/Methodology/Approach: Brewer and Hunter's approach was used to carry out an analysis of state financial support.

Findings: The findings suggest that the modern system of government financial support for SMEs in Switzerland is flexible and capable of effectively resisting financial crises and changes in global market conditions. Switzerland has one of the most powerful and secure banking systems in the world and modern scientific and educational capabilities based on its world famous universities. These conditions are self-sufficient in the innovative development of the economy, focusing on their own financial resources and the national scientific and educational environment.

Practical Implications: The experience of Switzerland can be applied in Russia to develop effective mechanisms for integrating academic and university sciences with public and private commercial industrial partners in order to accelerate the commercialization of scientific research. Such government policy instruments will make it possible to increase the level of state interaction in the sphere of education and science with the business sector, resolve the shortage of qualified specialists and accelerate the process of commercialization of research and development $(R \& D)$.

Originality/Value: The advanced approaches of the Swiss model of public financing for the SME sector can be applied in developing countries, especially in those with limited mineral and labor resources, and in implementing strategies to boost the ratio of SMEs in the economy and their contribution to it.
}

Keywords: Switzerland, Russia, government institutes, small and medium-sized enterprises, financial support, innovation.

JEL classification: $M 21$, O32, O38.

Paper Type: Research article.

Acknowledgement: This research article was funded by the Russian Foundation for Basic Research (Grant No. 19-410-230060).

Conflicts of Interest: The author declares there is no conflict of interest.

\footnotetext{
${ }^{1}$ PhD (Econ.), Associate Professor, Doctoral student, St. Petersburg State University Associate Professor, Kuban State University, Krasnodar, Russia, zvikky90@gmail.com;
} 


\section{Introduction}

In modern conditions it is impossible to achieve high efficiency in innovation and the development of small and medium-sized enterprises (SMEs) without a profound knowledge of the infrastructural elements of state regulation and support, the types and instruments of financing programs, and the specifics of the innovative activity of SMEs. Incorrect assessment and interpretation by the state of the needs of enterprises in the SME sector makes impossible the timely taking of adequate measures of operative regulation and forming of a favorable environment for development of entrepreneurship and generation of innovations.

The innovative activity of SMEs is the subject of numerous scientific studies (Aidis et al., 2012; Guo and Woo, 2016; Dutta et al., 2019; Toomsalu et al., 2019). A number of empirical studies have examined the influence of a favorable economic environment (Estrin et al., 2013; Bjørnskov and Foss, 2016) and financial support for the growth of SMEs and their innovative activities (Cromie, 2000; Aidis et al., 2012; Zabolotskaya, 2015). Some previous studies have examined negative factors (lack of business models, insufficient knowledge of market conditions, lack of financial resources) leading to a decrease in the level of employment and to the bankruptcy of enterprises (Carter and Van Auken, 2006) and the features of the innovative economies of Switzerland (Belov, 2014; Guo and Woo, 2016).

The principal goal of this research is to analyze the main programs and instruments for governmental financing of SMEs in Switzerland to identify their features as well as areas for possible application of the advanced experience of this country to improve the system of governmental financial regulation and support for SMEs in Russia.

Using Brewer and Hunter's methodological approach (Brewer, Hunter, 2006, p.4) this study was organized as follows: the first section presents a review of the literature and the aim of the research; the second section reviews the performance and policy of Government financial support with a particular focus on federal support institutions and programs and forms of financing in Switzerland in the modern world. Finally, the third section provides the results of the research, as well as recommendations for adapting advanced elements of the Swiss Model for Russia.

\section{Switzerland as Leader of the European Model of Innovative Development of Small and Medium-Sized Businesses}

Switzerland is a prominent representative of countries with a European economic development model. The European model $^{2}$ is focused on the development of statecorporate forms of support for SMEs both at the national and with EU countries at

\footnotetext{
${ }^{2}$ The European model of economic and innovative development includes major European countries (with the exception of the Scandinavian countries).
} 
the supranational level. The main features of this model are the development of a national network of support for entrepreneurship and business innovation centers with financing for SMEs in the form of public-private partnerships (Zabolotskaya, 2015; Toomsalu et al., 2019). Despite the fact that Switzerland is a small state it is characterized by a high level of economic and innovative development (Table 1).

Table 1. Key indicators of economic development in Switzerland (Worldmeters 2020).

\begin{tabular}{|l|c|}
\hline \multicolumn{1}{|c|}{ Indicator } & Value \\
\hline Population, (millions) (2020) & 8.6 \\
\hline Gross domestic product (GDP), (US\$ billions) (2019) & 608.7 \\
\hline GDP per capita, (US\$ thousands) (2019) & 70.95 \\
\hline Total expenditure, (US\$ billions) (2017) & 232.03 \\
\hline Expenditure on Education, (US\$ billions) (2015) & 34.7 \\
\hline $\begin{array}{l}\text { Expenditure on Education, percentage of total expenditure budget } \\
\text { (2015) }\end{array}$ & 15.53 \\
\hline Research and development (R\&D) expenses, (US\$ billions) (2017) & 18.5 \\
\hline Exports, (US\$ billions) (2018) & 310.5 \\
\hline Exports, percentage of GDP (2018) & 44.01 \\
\hline Ratio of SMEs to all enterprises in the country, \% (2018) & 99.7 \\
\hline
\end{tabular}

Source: Own study.

As could be seen from Table 1 the basis of the Swiss economy is SMEs that are actively engaged in innovative activities, are developing at an accelerated pace in the regions of the country and entering the international market. Swiss exports in 2018 amounted to $44.01 \%$ of GDP. The contribution of the SME sector to the country's GDP amounted to 99 percent. Switzerland is a leader in the field of innovative development and stimulation of the innovative activity of SMEs with a European model of state support. According to the Global Innovation Index (GII), Switzerland has maintained global leadership in innovation since 2011 (Dutta et al., 2019, p. 27).

The active introduction of technology and the innovative development of industry and SMEs in the Swiss Confederation and its cantons is a priority for the Governmental Policy (Belov, 2014). The Swiss Confederation allocated more than 3 percent of GDP to federal programs in the sphere of research and development (R\&D) from 2012 to 2017, and the volume of federal financing of this sphere increased by more than 1.3 times (Pastor and Sollberger, 2019; OECD, 2020). 
In 2017 about 72 percent of $R \& D$ expenditure was financed by private commercial and non-profit enterprises (63 percent of which were national companies), and 28 percent by the federal budget of the Swiss Confederation and universities (Figure 1).

Direct measures of state financing for SMEs at the federal and cantonal levels in the form of concessional state loans (up to 2/3 of the costs of the project) (Belov, 2014; Pastor and Sollberger, 2019), direct subordinated loans, microloans, state guarantees for bank loans and grants, including in the field of $\mathrm{R} \& \mathrm{D}$, are widespread in Switzerland, as well as partial reimbursement of interest on loans for SMEs and allowances for staff salaries at small enterprises for technical retraining or scientific internship. As a rule, these forms of support are mainly aimed at providing financing to those SMEs and startups that are actively involved in developing partnerships with research institutes and universities.

Figure 1: Intramural expenditure on $R \& D$ in Switzerland for the period 2008-2017 (CHF billions)

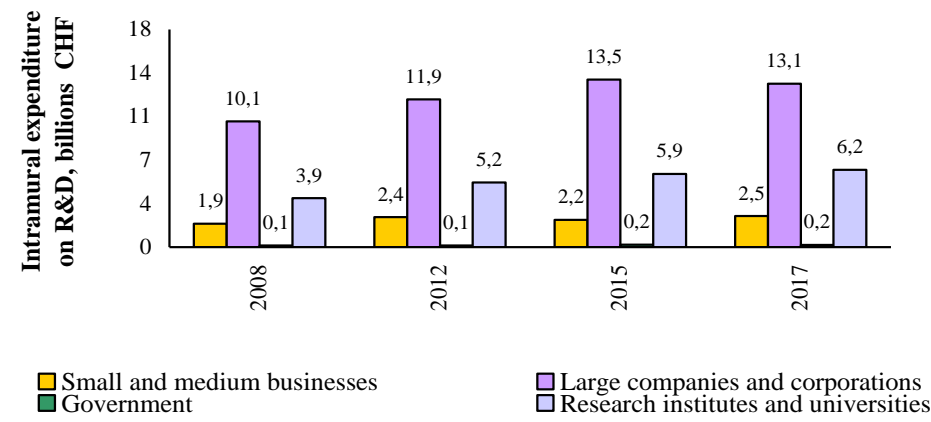

Source: Compiled by the author based on (Pastor and Sollberger, 2019).

The main infrastructural elements of financial support and development for the innovative activities of SMEs are:

1. The Federal Innovation Agency (Innosuisse). The key goals of Innosuisse are implementing the main government programs and monitoring the efficiency of financial resources directly or indirectly allocated through specialized funds. The key function of Innosuisse is to finance startups in priority areas of the national economy and joint projects between SMEs and universities, as well as the development of international cooperation. In the period from 2017 to 2020 the annual average volume of financial support for research and innovation amounted to CHF 22 million. For this period total expenses amounted more than CHF 916 million (Innosuisse, 2018).

2. The Swiss National Science Foundation (SNSF). The Foundation has delegated powers from the state to finance and market the results of basic research and projects 
by scientists and specialists. For SMEs this SNSF fund, together with Innosuisse, is implementing the BRIDGE Proof of Concept and BRIDGE Discover programs, which are aimed at co-financing interdisciplinary basic research and accelerating the commercialization of $\mathrm{R} \& \mathrm{D}$ results. The state compensates for expenses related to the payment of wages (up to CHF 13 000) and other project costs for a period of up to four years (Pastor and Sollberger, 2019).

3. The Institute for Commercial (Bank) Guarantees for SMEs (Commercial Guarantee Central Office, CGCO) (State Secretariat for Economic Affairs, 2013a). CGCO includes four regional commercial guarantee cooperatives: BG Mitte/CC Center, BG OST-SÜD, Cautionnement romand PME (CRC-PME) and a special loan guarantee institution for businesswomen (SAFFA Guarantee Cooperative for Women). Currently, CGCO and the regional commercial cooperatives have doubled the size of their loan guarantee to CHF 1 million. The Swiss Federal Government guarantee is up to 65 percent (Pastor and Sollberger, 2019).

4. Technology Fund provides guarantee support to SMEs whose field of activity is aimed at resolving environmental problems and the use of renewable energy sources. Credit guarantees are provided in the amount of 40 percent of the loan amount. The standard size of a loan guarantee cannot exceed CHF 3 million (Luterbacher, 2018; Technology Fund, 2019).

5. The Foundation pour l'Innovation Technologique (FIT) provides interest-free loans to startups. The maximum size of the loan is CHF 100000 (if other sources of financing are available) (Foundation for Innovations and Technologies, 2019).

A dense network of European Space Agency Business Incubation Centers (ESA BICs), technoparks and start-up centers complement the system of innovation development for SMEs in Switzerland. They facilitate the process of startup and development of student and youth innovative enterprises, which become members of the Swissparks.ch national association (European Space Agency, 2016). Their major purpose is to develop forms of collaboration by high-tech SMEs with universities and with financial intermediaries and investors such as investment and venture funds and business angels (Business Angels Switzerland), which become permanent residents of techno parks (Belov, 2014; Association of Swiss Technology Parks and Business Incubators, 2019). This method of integrated cooperation greatly facilitates the process of finding financial investment to develop youth innovation SMEs.

Table 2 gives a brief description of the main innovation programs available to Swiss SMEs. As can be seen from Table 2 Switzerland has developed favorable conditions for implementing comprehensive support for innovative startups at all stages of their business lifecycle. Particular attention is paid to the development of skills for innovation thinking and leadership of the younger generation (CTI, Bridge programs) and financing of fundamental research in priority areas of economy (Technology Fund, ESA BIC programs). 
A feature of the Swiss model is support, not to all innovative startups in general, but only to the best of them. Moreover, each program provides financial resources to no more than ten of the best enterprises or innovators. Although Switzerland is not a European Union (EU) member, since 2017 it has been officially participating in EU programs for innovation development such as Horizon 2020 and EUREKA (Luterbacher, 2018; European Commission, 2017).

In order to maintain a leading position in the field of innovative development of the country and increase the level of competitiveness of its economic entities in the national and international markets, Switzerland pays great attention to digitalization of the economy. As part of the implementation of the National eGovernment Strategy (eGovernment Strategy Switzerland (2016-2019)) the Easy Government online platform was created for interaction between authorized government regulatory and support authorities and entrepreneurs (EasyGov.swiss Version 1.0). Its functions include electronic processing of registration procedures and real-time value-added tax (VAT) payments by new companies and information on state support organizations, as well as providing insurance and other services (joinup, 2019). This platform operates continuously $24 / 7$ and offers delayed completion of registration forms. With this assistance Switzerland has already registered 14543 enterprises and more than 100000 companies have received VAT refunds (joinup, 2019; EasyGov, 2020).

The Swiss national state economic development policy for SMEs is coordinated with the European Commission's Strategy for the Development of the Digital Economy (Single Digital Market). To promote innovation and technological development in the EU markets, Switzerland actively cooperates with various European networks: ERA-NET, the European Space Agency Business Incubation Centers and a network of joint research by large corporations and SMEs with European industrial partners and universities in the field of nanoelectronics and computer systems (Electronic Components and Systems for European Leadership). This cooperation allows Switzerland to implement international projects and provides it with access to EU financing and its innovation market.

\section{Conclusions and Some Policy Implications}

Switzerland is a small country that does not have huge mineral or labor resources. These circumstances predetermined the innovative approach to developing the national economics with an orientation toward the development of knowledge-based SMEs. The mutual efforts of the government and private-commercial structures in this country has shaped a flexible multi-channeled and targeted financial support system for the SME sector focused on the development of priority areas of the economy and forming favorable conditions for doing business at all stages of a SME's life cycle. 
Table 2. Government programs of financial and guarantee support for innovative activities of SMEs in Switzerland

\begin{tabular}{|c|c|c|c|}
\hline $\begin{array}{l}\text { Institut } \\
\text { ion }\end{array}$ & Program & Brief Description & $\begin{array}{c}\text { Form of Governmental Financial Support for } \\
\text { Innovative Activities of SMEs }\end{array}$ \\
\hline \multirow{5}{*}{$\begin{array}{c}\text { Innosuis } \\
\text { se }\end{array}$} & CTI Start-up & \multirow[b]{2}{*}{$\begin{array}{lr}\text { Payroll funding for } \\
\text { researchers participating } \\
\text { in selected innovative } \\
\text { projects } \\
\text { Three-stage } & \text { financial } \\
\text { support } & \text { for } \\
\text { reimbursement } & \text { of } \\
\text { coaching } & \text { services } \\
\text { depending on the stage of } \\
\text { training (initial stage, up } \\
\text { to CHF 5 000; main } \\
\text { stage, 50 000; final stage, } \\
75000)\end{array}$} & \multirow[b]{2}{*}{$\begin{array}{l}\text { Assisting in the search for financing and fundraising to } \\
\text { implement business ideas of innovators and entry onto } \\
\text { global markets } \\
\text { Financing joint research projects by SMEs and } \\
\text { universities } \\
\text { Providing start-ups with online services (registration } \\
\text { service, online guides, information checklists, accounting } \\
\text { support, consulting on the startup process, etc) } \\
\text { Financing for internships in world centers of high } \\
\text { technology and innovation for senior employees at the top } \\
\text { ten startups in the country } \\
\text { Individual training to promote new ideas and business } \\
\text { projects by young entrepreneurs }\end{array}$} \\
\hline & $\begin{array}{l}\text { CTI } \\
\text { Entrepreneurs } \\
\text { hip }\end{array}$ & & \\
\hline & CTI Invest & $\begin{array}{l}\text { Assistance for young } \\
\text { entrepreneurs who have } \\
\text { already completed } \\
\text { training under CTI } \\
\text { programs or won the CTI } \\
\text { Start-up Label Award }\end{array}$ & Assistance in investment fundraising \\
\hline & $\begin{array}{l}\text { BRIDGE } \\
\text { Proof of } \\
\text { Concept }\end{array}$ & \multirow{2}{*}{$\begin{array}{l}\text { Reimbursement of direct } \\
\text { expenses (salary) of SME } \\
\text { business projects } \\
\text { The maximum amount of } \\
\text { financing is CHF } 13000 \\
\text { Term: } 12 \text { months to } 4 \\
\text { years }\end{array}$} & \multirow[t]{2}{*}{$\begin{array}{l}\text { Joint financing with the Swiss National Science } \\
\text { Foundation of interdisciplinary in-depth research and } \\
\text { innovation } \\
\text { Assisting in commercializing the research results of } \\
\text { innovators }\end{array}$} \\
\hline & $\begin{array}{l}\text { BRIDGE } \\
\text { Discovery }\end{array}$ & & \\
\hline $\begin{array}{l}\text { Europea } \\
\text { n Space } \\
\text { Agency }\end{array}$ & $\begin{array}{l}\text { ESA BIC } \\
\text { technology } \\
\text { transfer }\end{array}$ & $\begin{array}{l}\text { Two-stage financial } \\
\text { support for up to ten } \\
\text { startups for a period of up } \\
\text { to } 2 \text { years } \\
\text { First stage } € 50 \quad 000 \text {, } \\
\text { second stage } € 450000\end{array}$ & $\begin{array}{l}\text { Financing of SMEs specializing in matters related to } \\
\text { Space } \\
\text { Network access to Impact Hubs }\end{array}$ \\
\hline
\end{tabular}

Source: Retrieved by the author from: (State Secretariat for Economic Affairs, 2013b; European Space Agency, 2016; Brunner, 2019).

At the same time, the peculiarities of the geographical location of Switzerland, its various socio-economic conditions and its scientific and educational levels determined the specifics of its innovative development. Switzerland has one of the most powerful and safest banking systems in the world and an advanced scientific and educational base with world-famous universities. These conditions are sufficient for the innovative development of the economy, focusing on its own financial resources and national scientific and educational environment. At the same time, the Swiss financial support system is concentrated mainly on start-ups and SMEs whose activities are aimed at producing high-tech products, services and technologies and promoting them on the international market. 
Despite the enormous differences in the territory, population and level of socioeconomic development of Russia compared with such small country as Switzerland, its experience of innovative economic development and the system of financial support for SMEs can be very useful.

One of the crucial problems in Russia at the present stage is the integration of academic and university science with governmental infrastructure institutions and private-commercial industrial partners in order to accelerate the commercialization of scientific research results. Many elements and approaches of the Swiss model are aimed at financing support to innovations from small enterprises owned by youth or students and to startup centers and technology parks and can be adapted in Russia to take into account its national characteristics. These measures will make it possible to significantly increase the level of interaction by higher education and scientific institutions with the Government and the business sector and resolve the issues of improving higher education and training for qualified specialists and accelerating the process of commercialization of R\&D and innovations.

The experience of Switzerland can be also used in the development of international cooperation in the field of innovation in digital and IT technologies, attracting foreign investors and highly qualified talented specialists, and introducing new technologies, goods and services to the EU and global market.

The approaches developed in the Swiss model of public financing and other types of assistance to the SME sector can be applied in other developing countries, especially in those with limited mineral or labor resources, as well as in national strategies being implemented to increase the share and contribution of SMEs to economic development.

\section{References:}

Aidis, R. Estin, S., Mickiewicz, T.M. 2012. Size Matters: Entrepreneurial Entry and Government. Small Business Economics, 39, 119-139. doi:10.1007/s11187-0109299-y.

Association of Swiss Technology Parks and Business Incubators, 2019. Promoting Innovation \& High-Technology Start-ups. Available online: http://www.swissparks.ch.

Belov, N.I. 2014. Features of the industrial policy of Switzerland, support for innovation. Russian Foreign Economic Bulletin, 7, 105-117.

Bjørnskov, C., Foss, N. 2016. Institutions, Entrepreneurship, and Economic Growth: What Do We Know and What Do We Still Need to Know? Academy of Management Prospect, 30, 292-315, doi:10.5465/amp.2015.0135.

Brasharan, M. 2018. Getting Singapore in shape: Economic challenge and how to meet them. Lowy Institute. June. 26p. Available online: https://www.lowyinstitute.org/sites/default/files/Manu\% 20Bhaskaran_Getting\%20Singapore\%20in\%20shape_WEB_2.pdf. 
Brewer, J., Hunter, A. 2006. Foundations of Multimethod Research. Sage Publications Inc. https://dx.doi.org/10.4135/9781412984294.

Brunner, C.B. 2019. Swiss National Science Foundation. Available online: http://www.snf.ch/en/funding/programmes/bridge/Pages/default.aspx.

Carter, R., Van Auken, H. 2006. Small Firm Bankruptcy. Journal of Small Business Management, 44, 493-512. doi:10.1111/j.1540-627X.2006.00187.x.

Cromie, S. 2000. Assessing Entrepreneurial Inclination: Some Approaches and Empirical Evidence. European Journal of Work and Organizational Psychology, 9, 7-30. doi:10.1080/135943200398030.

Dutta, S., Lanvin, B., Wunsch-Vincent, S. 2019. The Global Innovation Index 2019.

Creating Healthy Lives-The Future of Medical Innovation. Cornell University. INSEAD, WIPO. 451p. Available online: https://www.wipo.int/global_innovation_index/en/2019/.

EasyGov. 2020. EasyGov Usage Statistics. Available online: https://www.easygov.swiss/easy-gov/\#/en/public/usage-statistics.

Estrin, S., Korosteleva J., Mickiewicz, T. 2013. Which Institutions Encourage Entrepreneurial Growth Aspirations? Journal of Business Venturing, 28, 564-580. doi:10.1016/j.jbusvent.2012.05.001.

European Commission. 2017. Swiss Participation in Horizon 2020. January. 3p. Available online: https://ec.europa.eu/research/partici-pants/data/ref/h2020/other/hi/h2020-hiswiss-part_en.pdf.

European Space Agency. 2016. Attractive Opportunities for Swiss Entrepreneurs. Technology Transfer Programme. November 11. Available online: https://www.esa.int/Our_Activities/Telecommunications_Integrated_Applications/TT P2/Attractive_opportunities_for_Swiss_entrepreneurs.

Foundation for Innovations and Technologies. 2019. The Foundation for Technological Innovation Provides Financial Supports to Innovative and Technological Projects at Different Development Stages. Available online: https://fondation-fit.ch/en/.

Guo, Y., Woo, J.J. (eds). 2016. Singapore vs Switzerland: Secrets of Small State Success. Singapore, World Scientific Pub. Co. Inc., 303p.

Innosuisse. 2018. Innosuisse Replaces CTI: Funding Opportunities for Swiss Researchers, SMEs and Industry. February 15. Available online: http://www.accelopment.com/blog/innosuisse-replaces-cti-funding-opportunitiesfor-swiss-researchers-smes-and-industry.

Joinup. 2019. Digital Government Factsheets-Switzerland 2019. Available online: https://joinup.ec.europa.eu/collection/nifo-national-interoperability-frameworkobservatory/digital-government-factsheets-2019.

Luterbacher, C. 2018. A New Model for Swiss Innovation. SWI. Swiss info.ch., July 11. Available online: https://www.swissinfo.ch/eng/risky-business_a-new-model-forswiss-innovation/44031292.

OECD. 2020. Gross domestic spending on R\&D (indicator). Available at: https://data.oecd.org/rd/gross-domestic-spending-on-r-d.htm.

Pastor, E., Sollberger, P. 2019. Research and development in Switzerland 2017. In Finances and Personnel. Neuchâtel: Federal Statistical Office, 32p. Available online: https://www.bfs.admin.ch/bfs/de/home/statistiken/katalogedatenbanken/publikatione n.assetdetail.347782.html.

State Secretariat for Economic Affairs. 2013a. Commercial guarantees. In Report on the Practicability, Effectiveness and Cost Effectiveness of the Federal Law on Financial 
Aid for Commercial Guarantee Organizations. Report of the Federal Council. Federal Council, Bern. 51p.

State Secretariat for Economic Affairs, 2013b. Switzerland's SME Policy. Federal Department of Economic Affairs, Education and Research EAER, Bern. November 25. 38p. Available online: https://www.seco.admin.ch/seco/en/home/Standortfoerderung/KMU-Politik.html.

Technology Fund. 2019. Loan Guarantees. Bridging the Gap between Start-up Funding and Regular Corporate Loans for SMEs. Available online: http://www.technologyfund.ch/loan-guarantees/.

The Federal Council of Switzerland. 2016. Figures on SMEs: Companies and Jobs. SME Portal for Small and Medium-Sized Enterprise. Available online: https://www.kmu.admin.ch/kmu/en/home/sme-policy/facts-and-figures/figuressmes/companies-and-jobs.html.

Toomsalu, L., Tolmacheva, S., Vlasov A., Chernova, V. 2019. Determinants of innovations in small and medium enterprises: A European and International experience. Terra Economicus, 17, 112-123. doi:10.23683/2073-6606-2019-17-2-112-123.

World Bank Group. 2019. Doing Business 2019. Training for Reform. 311p. Available online: http://www.worldbank.org/content/dam/doingBusiness/media/AnnualReports/English/DB2019-report_web-version.pdf .

Zabolotskaya, V.V. 2015. State financial support of innovative activity of small and medium enterprises abroad. Finance and Credit, 25, 31-43. 